\title{
EVALUATION AND USE OF GENETIC RESOURCES IN SPRING MALTING BARLEY BREEDING IN LITHUANIA
}

\author{
Algè Leistrumaitè, Vanda Paplauskienè, and Audronè Mašauskienè
}

Lithuanian Institute of Agriculture, Akademija, Kèdainiai distr., Instituto al. 1, LT-58344, LITHUANIA

E-mail: alge@Izi.It, vanda @Izi.It, audrone.masauskiene@ Izi.It

Communicated by İzaks Rašals

\begin{abstract}
During the period 2004-2006, grain yield stability and malt quality characteristics of 47 spring barley varieties and 55 promising breeding lines from the collection of spring barley genetic resources were investigated at the Lithuanian Institute of Agriculture (LIA). The growing conditions in 2004 were fairly normal compared with the long-term mean, and the years 2005 and 2006 were rather dry. The varieties and breeding lines tested showed from medium to high variation of grain $>2.5 \mathrm{~mm}$ yield (CV 11.5-34.3\%) and medium variation of grain yield (CV 4.39-13.33\%). However, high temperatures and drought in June of 2006 caused a low grain $>2.5 \mathrm{~mm}$ yield (by on average 55.0-67.8\%). Promising breeding lines were characterised as having higher grain yield and extract output per ha compared with barley varieties. However, the data showed that grain grading $2.5 \mathrm{~mm}$ should be improved for the breeding lines. Using the software STABLE we estimated the stability of malting barley quality traits in relation to weather conditions during the crop year, genotype properties for varieties and breeding lines, as well as the interactions of variety and weather conditions. The selection of lines promising in terms of grain yield, $>2.5 \mathrm{~mm}$ grain yield and extract yield, was based on their ability to realise the genetic potential in various growing conditions. The highest score in integral assessment of grain yield, grain $>2.5 \mathrm{~mm}$ yield and extract yield was identified for the varieties 'Tocada', 'Sebastian', 'Scarlett' and breeding lines: 7939-1, 7661-1, and 8080-4. The varieties and breeding lines that exhibited high grain stability, high grain quality and other agronomic traits were utilised in further breeding programmes.
\end{abstract}

Key words: Hordeum vulgare $L$, genetic resources, yield stability, malting quality traits.

\section{INTRODUCTION}

Barley is a major crop in the world used for food, feed and malt. About $10 \%$ of the worldwide obtainable barley harvest is used for malt production in the brewing industry (Tamm and Tamm, 2002). However, only 10-12 million ha are suitable for malting barley growing. In Lithuania barley has been cultivated since ancient times. The sufficiently humid (annual precipitation rate from 450 to $650 \mathrm{~mm}$ ) climate and warm summers enable barley to perform well. Barley is one of the most common crops in Lithuania. In 2006, its cultivation area covered 376.8 thousand hectares and accounted for $62.3 \%$ of the total spring cereal area (Anonymous, 2006).

The development of the malting and brewing industry in Europe and today's modernisation increased the interest in malting barley quality improvement. The variability of genetic resources, which are the initial material for breeding programmes, needs to be evaluated before the resource is utilised in breeding. Agromorphological traits are com- monly used for this purpose. However, they are influenced by environmental factors and growing conditions, and therefore, are of limited use for assessing the levels of variability. The genotypic features of a variety and climatic conditions over the growing period are key factors influencing grain yield and quality (Tamm, 2003; Paynter and Young, 2004; Lazauskas et al., 2005). The first step for success in the malting barley growing systems is choice of an appropriate variety. The barley grain for malting purposes must meet specific requirements. Therefore, the evaluation of genetic diversity of initial material and matching of individuals with suitable traits for the malting barley breeding programmes are of primary importance. This objective is not easily achieved, as high yield and grain quality parameters need to be combined. This has been shown in countries with malting barley growing traditions and with lengthy agrarian science experience (Bail and Meynard, 2003).

Coarse grain output (grain on $2.5 \times 20 \mathrm{~mm}$ sieve) is specific to malting barley, which according to the present brewing 
requirements must be not less than $90.0 \%$. The weather conditions (humidity and temperature) over the grain filling period affect the output (Paynter and Young, 2004; Passarella et al., 2005). Grain protein content is important in the brewing process as it affects beer quality, and hence this parameter is on the list of breeders considerations. A higher protein content reduces malt extract and also final beer quality (Leach, 2002). In contrast, lower grain protein content correlates with good malt quality (Eagles et al., 1995; MolinaCano et al., 1997; Zhang et al., 2006). A strong correlation exists between grain protein content and extract content, and regression equations have been developed to perform evaluation of malt extractivity (Ivoilov, 2003). Spring barley varieties and breeding lines differ according to their reaction to growing conditions, and therefore, yield and grain quality traits vary over a wide range (Costa and Bollero, 2001; Mašauskienè et al., 2001). In Lithuania air temperature significantly varies among years for summer months starting from the seventh decade, and every second or third summer is much colder or much hotter than the long-term mean (Bukantis, 2001). The weather conditions during the growing period are among the main factors of affecting malting barley yield and especially grain and malt quality (Passarella et al., 2005). Mathematical models used for analysis of varietal grain yield stability (Tarakanovas, 2004) allow us to estimate genotype and environment interactions and to select the most valuable varieties and breeding lines.

The objectives of this study were to assess grain, coarse grain and extract yield and stability of these parameters in spring barley genetic resources and to select the most promising lines for malting barley breeding programmes.

\section{MATERIALS AND METHODS}

Grain yield stability and malt quality characteristics of 47 spring barley varieties from Germany, Denmark, Sweden, Great Britain, France, Netherlands, and Lithuania, and 55 LIA promising breeding lines from the collection of spring barley genetic resources were investigated at the Lithuanian Institute of Agriculture during 2004-2006. All investigated varieties were of two row type. The spring barley varieties and breeding lines were grown on the $20 \mathrm{~m}^{2}$ plots with a standard level of fertilization $\mathrm{N}_{90} \mathrm{P}_{60} \mathrm{~K}_{60}$ ( $\mathrm{P}$ and $\mathrm{K}$ oxides). Experiments were carried out using a randomised block design with four replications. The soil of the experimental site was a Endocalcari-Epihypogleyic Cambisol (CMg-p-w-can) light loam. Legumes were the preceding crop. A German malting spring barley variety 'Barke' was used as a control variety.

The period 2004-2006 was rather favourable for spring barley versatile evaluation because of variable weather conditions (2004 - wet, 2005 - dry, 2006 - hot and dry). For better evaluation of humidity and temperature regime during the growing season, the hydrothermal coefficient (HTC) was calculated using the scale recommended by Czech scientists and used in Lithuania: HTC $\leq 1.0$ dry; HTC = 1.0-1.3 - medium dry; HTC $=1.3-1.6-$ optimal moisture; HTC $\geq 1.6$ wet (Lazauskas et al., 2005) (Table 1).
Table 1

HYDROTHERMAL COEFFICIENT (HTC) DURING THE GROWING PERIOD IN DOTNUVA, 2004-2006

\begin{tabular}{l|c|c|c|c|c}
\hline \multicolumn{1}{c|}{ Year } & April & May & June & July & August \\
\hline 2004 & 1.3 & 1.1 & 1.0 & 1.6 & 1.7 \\
2005 & 2.5 & 1.6 & 1.1 & 0.8 & 1.4 \\
2006 & 2.7 & 1.3 & 0.1 & 0.6 & 1.8
\end{tabular}

In the trials we evaluated grain yield $\left(\mathrm{t} \cdot \mathrm{ha}^{-1}\right), 1,000$ kernel weight (TKW) $(\mathrm{g})$, hectolitre weight (HLW) $\left(\mathrm{g} \cdot \mathrm{l}^{-1}\right)$. Malt extract content $(\%)$, protein content $(\%)$, starch content $(\%)$, and grain grading $>2.5 \mathrm{~mm}(\%)$ were determined in grain. Protein content was measured by the Kjeldahl method, starch content by hydrochloric acid dissolution. Malt extract content was determined on the basis of EBC (AnalyticaEBC, 1987). Output of coarse (> $2.5 \mathrm{~mm}$ ) grain and extract yield per hectare were calculated.

The level of statistical significance of data was calculated by the analysis of variance using the software ANOVA (Tarakanovas, Raudonius, 2003). The mean value $\bar{X}$, standard error of the mean $S_{\bar{X}}$ and the least significant difference $\mathrm{LSD}_{05}$ were introduced. Stability of traits was evaluated by the computer programme STABLE (Kang, Magari, 1995; Kang, 2003) adapted at LIA by P. Tarakanovas (2004). The scores scales used are as follows:

Scores for evaluation by productivity:

$X_{\mathrm{i}}>X . .=1$,

$X_{\mathrm{i}}>=X . .+\mathrm{LSD}_{05}=2$,

$X_{\mathrm{i}}>=X . .+2 * \mathrm{LSD}_{05}=3$,

$X_{\mathrm{i}}<X . .=-1$,

$X_{\mathrm{i}}<X . .-\mathrm{LSD}_{05}=-2$,

$X_{\mathrm{i}}<X . .-2 * \mathrm{LSD}_{05}=-3$,

where $X_{\mathrm{i}}$ mean yield of $i$ variety, $X-$ mean yield of trial, $\mathrm{LSD}_{05}$ - the least significant difference.

Scores for evaluation by stability:

$\sigma^{2}{ }_{i}<\mathrm{F}_{\text {teor } 0,1}=0$,

$\sigma_{i}^{2}>=F_{\text {teor } 0,1}=-2$,

$\sigma_{i}^{2}>=F_{\text {teor } 0,05}=-4$,

$\sigma_{i}^{2}>=F_{\text {teor } 0,01}=-8$,

where $\sigma_{i}^{2}$ - diversity of variety stability (Shukla, 1972), $\mathrm{F}_{\text {teor }}-$ Fisher's teoretical test for levels of reliability.

Integral evaluation of varieties and breeding lines was based on rank evaluation of sum of scores for grain yield and stability. Varieties with the highest sum of scores were considered as the best. 
Significant differences in grain yield, grain $>2.5 \mathrm{~mm}$ yield and extract yield were found for the experimental year, variety genotype and breeding line (Table 2). An effect of variety and year interaction was also observed. Therefore, significant differences $(P<0.01)$ among varieties provided a solid basis to continue analysis for selection of the best breeding material.

For the varieties usually the highest grain yield was harvested in $2004\left(5.11 \mathrm{t} \cdot \mathrm{ha}^{1}\right)$ and the lowest in 2006 (4.02 t.ha ${ }^{-1}$ ) (Table 3). In 2004, the most favourable for spring barley, the grain yield of the standard variety 'Barke' was high and there were no varieties that surpassed it. In 2005, $58.8 \%$ of the tested varieties and in $2006,40.2 \%$ produced higher grain yield than the standard variety. The examined spring barley breeding lines were characterised by higher grain, grain $>2.5 \mathrm{~mm}$ and extract yields compared to varieties. The varieties and breeding lines were characterised by high variation of grain $>2.5 \mathrm{~mm}$ yield (CV 11.5-34.3\%) and moderate variation for grain yield (CV 4.39-13.33\%).

The compatibility of high yield and grain yield stability performance is an informative characteristics for the selection of the best crop varieties and breeding lines. The STABLE programme was used to assess (Table 4) spring barley varieties and breeding lines according to grain yield and stability. The varieties, which surpassed the average integral evaluation of the trials are indicated by a (+). Among the varieties and breeding lines evaluated during 2004-2006, the varieties 'Tocada' (21+), 'Sebastian' (13+), 'Scarlett' (7+) and the Lithuanian variety 'Aura DS' (6+) received an especially high integral assessment. These varieties combine high yield (5.2-4.4 tha ${ }^{-1}$ ) with low variance of stability $\left(\sigma^{2}\right)(0.004-0.113)$.

Table 5 provides the grain quality data for the spring barley varieties and breeding lines that were characterised by grain yield stability. Breeding line 7967-2 was distinguished by low protein content (12.9\%), and for high extract content (78.9\%), and breeding lines 7661-1, 8080-4 and 7967-2 by high starch content (59.3-60.8\%). Breeding line 8163-1 had a high grain grading value $(82.6 \%)$.
ANALYSIS OF VARIANCE OF SPRING BARLEY GRAIN, GRAIN $>2.5$ MM AND EXTRACT YIELDS, DOTNUVA, 2004-2006

\begin{tabular}{l|c|c|c|c}
\hline \multirow{2}{*}{ Dispersion } & \multirow{2}{*}{ DF } & \multicolumn{3}{|c}{ Mean square of the yield (MS) } \\
\cline { 3 - 5 } & & grain tha ${ }^{-1}$ & $\begin{array}{c}\text { grain }>2.5 \\
\text { mm thha }\end{array}$ & extract t.ha ${ }^{-1}$ \\
\hline Varieties (V) & 18 & $6.038^{*}$ & $3.396^{*}$ & $6.21^{*}$ \\
Year (Y) & 3 & $638.658^{*}$ & $2730.411^{*}$ & $922.424^{*}$ \\
Interaction $(\mathrm{V} \times \mathrm{Y})$ & 54 & $7.259^{*}$ & $21.701^{*}$ & $9.246^{*}$ \\
Heterogeneity & 18 & 0.524 & 0.553 & 0.376 \\
Standard error & 153 & 0.049 & 0.027 & 0.028
\end{tabular}

$* P<0.01$

\section{DISCUSSION}

The widely different climatic conditions in the three experimental seasons effected barley productivity and quality resulting in CV from 10.52 to $13.33 \%$ for varieties grain yield. Grain yield variation of spring malting barley in Estonian conditions was moderate - in separate years $(\mathrm{CV}$ $12-16 \%)$ (Tamm, 2003). The CV for grain yield in Lithuania was slightly lower than that in Estonia. In our experiment the weather according to HTC in 2004 April-June was moderately dry, but at the grain filling period in July-August moisture was optimal. Therefore, the total yield was high. Grain embryo formation stage begins immediately after tillering stage, while grain filling continues from its set till maturity. The optimal moisture conditions during the grain setting-filling period secure good yield. Drought stress after flowering increases dry matter amount in grain, while shortening of grain filling period negatively affects grain yield and quality (Samarah, 2005). A low yield was obtained in 2006 because April and May were wet and June and July were dry. In 2005, the weather in April and May was wet, in June moderately dry, and July was dry. These weather conditions promoted moderate and low variation of yield for varieties and also breeding lines. In Lithuanian conditions spring barley reaches the grain filling stage in July. In the three experimental years HTC of that month varied in a wide range (from 0.6 in 2006 to 1.6 in 2004). However, the highest coefficient of variation for grain $>$

Table 3

VARIATION OF SPRING BARLEY VARIETIES AND BREEDING LINES' GRAIN, GRAIN > $2.5 \mathrm{~mm}$ AND EXTRACT YIELD, DOTNUVA, 2004-2006

\begin{tabular}{|c|c|c|c|c|c|c|c|c|c|}
\hline \multirow[t]{3}{*}{ Indicator } & \multicolumn{9}{|c|}{ Years } \\
\hline & \multicolumn{3}{|c|}{2004} & \multicolumn{3}{|c|}{2005} & \multicolumn{3}{|c|}{2006} \\
\hline & $\bar{X}$ & $\mathrm{~S}_{\overline{\mathrm{X}}}$ & $\mathrm{CV} \%$ & $\overline{\mathrm{X}}$ & $\mathrm{S}_{\overline{\mathrm{X}}}$ & $\mathrm{CV} \%$ & $\bar{X}$ & $\mathrm{~S}_{\overline{\mathrm{X}}}$ & $\mathrm{CV} \%$ \\
\hline \multicolumn{10}{|c|}{ Varieties } \\
\hline Grain, tha-ha-1 & 5.11 & 0.189 & 13.33 & 4.44 & 0.080 & 10.52 & 4.02 & 0.073 & 10.78 \\
\hline Grain $>2.5 \mathrm{~mm}$, tha- 1 & 4.33 & 0.188 & 15.71 & 3.99 & 0.089 & 13.16 & 2.70 & 0.087 & 18.98 \\
\hline Extract, tha-1 & 4.01 & 0.169 & 15.23 & 3.23 & 0.199 & 13.77 & 3.06 & 0.061 & 11.83 \\
\hline \multicolumn{10}{|c|}{ Breeding lines } \\
\hline Grain, t.ha-1 & 5.53 & 0.067 & 7.31 & 5.04 & 0.074 & 8.44 & 4.12 & 0.031 & 4.39 \\
\hline Grain $>2.5 \mathrm{~mm}$, tha- 1 & 4.37 & 0.104 & 14.22 & 4.16 & 0.083 & 11.50 & 2.30 & 0.135 & 34.31 \\
\hline Extract, tha-1 & 4.34 & 0.057 & 7.95 & 4.03 & 0.054 & 7.22 & 3.11 & 0.028 & 5.19 \\
\hline
\end{tabular}


Table 4

ASSESSMENT OF SPRING BARLEY VARIETIES AND BREEDING LINES ACCORDING TO GRAIN YIELD, GRAIN > 2.5 mm AND EXTRACT YIELD AND STABILITY, DOTNUVA, 2004-2006

\begin{tabular}{|c|c|c|c|c|c|c|c|c|c|c|}
\hline \multirow{2}{*}{$\begin{array}{c}\text { Variety, } \\
\text { breeding line }\end{array}$} & \multirow{2}{*}{$\begin{array}{l}\text { Country } \\
\text { of } \\
\text { origin* }\end{array}$} & \multicolumn{3}{|c|}{ Grain yield, tha- 1} & \multicolumn{3}{|c|}{ Grain $>2.5 \mathrm{~mm}$, t.ha-1 } & \multicolumn{3}{|c|}{ Extract yield, t.ha-1 } \\
\hline & & $\bar{X}$ & $S_{\bar{X}}$ & $\begin{array}{c}\text { integral } \\
\text { assessment } \\
\text { (rank) }\end{array}$ & $\bar{X}$ & $S_{\bar{X}}^{-}$ & $\begin{array}{c}\text { integral } \\
\text { assessment } \\
\text { (rank) }\end{array}$ & $\bar{X}$ & $\mathrm{~S}_{\bar{X}}$ & $\begin{array}{l}\text { integral } \\
\text { assessment } \\
\text { (rank) }\end{array}$ \\
\hline Barke & $\mathrm{DE}$ & 4.71 & 0.279 & 5 & 4.08 & 0.260 & $11+$ & 3.76 & 0.251 & $8+$ \\
\hline Auksiniai 3 & $\mathrm{LT}$ & 3.60 & 0.049 & -10 & 3.14 & 0.112 & -8 & 2.85 & 0.062 & -10 \\
\hline Aidas & LT & 3.80 & 0.108 & -9 & 2.76 & 0.222 & -10 & 2.88 & 0.105 & -9 \\
\hline Luokè & LT & 4.27 & 0.089 & -4 & 3.56 & 0.152 & 1 & 3.21 & 0.097 & -6 \\
\hline Ūla & $\mathrm{LT}$ & 4.00 & 0.122 & -2 & 3.49 & 0.178 & -2 & 2.99 & 0.114 & -4 \\
\hline Aura DS & $\mathrm{LT}$ & 4.43 & 0.169 & $6+$ & 3.65 & 0.273 & $10+$ & 3.35 & 0.141 & 5 \\
\hline Alsa & LT & 4.19 & 0.136 & 3 & 3.40 & 0.231 & 2 & 3.21 & 0.120 & 1 \\
\hline Antto & SE & 3.87 & 0.376 & 0 & 3.56 & 0.268 & $4+$ & 3.32 & 0.199 & -4 \\
\hline Scarlett & $\mathrm{DE}$ & 4.68 & 0.164 & $7+$ & 4.09 & 0.279 & $12+$ & 3.73 & 0.154 & $7+$ \\
\hline Tocada & $\mathrm{DE}$ & 5.22 & 0.127 & $21+$ & 4.14 & 0.213 & $17+$ & 4.11 & 0.129 & $21+$ \\
\hline Sebastian & DK & 4.89 & 0.184 & $13+$ & 4.01 & 0.280 & $16+$ & 3.86 & 0.175 & $11+$ \\
\hline 7661-1 & LT & 4.77 & 0.145 & $15+$ & 3.77 & 0.290 & $6+$ & 3.70 & 0.124 & $9+$ \\
\hline $7695-4$ & $\mathrm{LT}$ & 4.59 & 0.208 & 2 & 3.42 & 0.321 & -5 & 3.41 & 0.172 & -1 \\
\hline 7939-1 & LT & 4.83 & 0.219 & $12+$ & 3.53 & 0.278 & $7+$ & 3.72 & 0.173 & $14+$ \\
\hline $8080-4$ & $\mathrm{LT}$ & 4.92 & 0.289 & $11+$ & 3.83 & 0.384 & $7+$ & 3.81 & 0.248 & $10+$ \\
\hline $8096-4$ & $\mathrm{LT}$ & 4.55 & 0.214 & $9+$ & 3.48 & 0.302 & -3 & 3.50 & 0.196 & $8+$ \\
\hline 8163-1 & $\mathrm{LT}$ & 4.73 & 0.268 & $6+$ & 6.78 & 2.859 & $9+$ & 3.69 & 0.233 & 4 \\
\hline $7967-2$ & $\mathrm{LT}$ & 4.94 & 0.184 & $20+$ & 2.78 & 0.384 & -9 & 3.90 & 0.158 & $20+$ \\
\hline Mean & & 4.51 & & 5.8 & 3.59 & & 3.6 & 3.500 & & 4.7 \\
\hline LSD05 & & 0.179 & & & 0.132 & & & 0.136 & & \\
\hline
\end{tabular}

* LT - Lithuania, DE - Germany, DK - Denmark, SE - Sweden

Table 5

GRAIN QUALITY TRAITS OF SPRING BARLEY VARIETIES AND BREEDING LINES, DOTNUVA, 2004-2006

\begin{tabular}{|c|c|c|c|c|c|c|c|c|c|c|c|c|c|}
\hline \multirow[t]{2}{*}{$\begin{array}{l}\text { Variety/ } \\
\text { line }\end{array}$} & \multirow{2}{*}{$\begin{array}{c}\text { Country } \\
\text { of } \\
\text { origin* }\end{array}$} & \multicolumn{2}{|c|}{$\begin{array}{c}\text { TKW } \\
\mathrm{g}\end{array}$} & \multicolumn{2}{|c|}{$\begin{array}{c}\text { HLW } \\
\mathrm{g} 1-1 \\
\end{array}$} & \multicolumn{2}{|c|}{$\begin{array}{c}\text { Protein } \\
\% \\
\end{array}$} & \multicolumn{2}{|c|}{$\begin{array}{c}\text { Starch } \\
\%\end{array}$} & \multicolumn{2}{|c|}{$\begin{array}{c}\text { Extract } \\
\% \\
\end{array}$} & \multicolumn{2}{|c|}{$\begin{array}{c}\text { Grading } \\
>2.5 \mathrm{~mm} \%\end{array}$} \\
\hline & & $\overline{\mathrm{X}}$ & $\mathrm{S}_{\overline{\mathrm{X}}}^{-}$ & $\overline{\mathrm{X}}$ & $\mathrm{S}_{\overline{\mathrm{X}}}^{-}$ & $\overline{\mathrm{X}}$ & $\mathrm{S}_{\overline{\mathrm{X}}}^{-}$ & $\overline{\mathrm{X}}$ & $\mathrm{S}_{\overline{\mathrm{X}}}^{-}$ & $\overline{\mathrm{X}}$ & $\mathrm{S}_{\overline{\mathrm{X}}}$ & $\overline{\mathrm{X}}$ & $\mathrm{S}_{\overline{\mathrm{X}}}^{-}$ \\
\hline Barke & $\mathrm{DE}$ & 49.2 & 1.01 & 639 & 22.9 & 13.3 & 0.82 & 60.4 & 0.93 & 79.3 & 1.67 & 85.7 & 5.01 \\
\hline Luokè & $\mathrm{LT}$ & 49.6 & 1.31 & 621 & 21.4 & 13.1 & 1.05 & 56.4 & 1.56 & 75.6 & 1.62 & 83.6 & 5.46 \\
\hline Auksiniai 3 & $\mathrm{LT}$ & 44.9 & 1.71 & 679 & 20.8 & 13.9 & 0.82 & 60.0 & 1.26 & 78.3 & 1.42 & 85.8 & 5.38 \\
\hline Aidas & $\mathrm{LT}$ & 46.2 & 1.55 & 647 & 17.3 & 14.6 & 0.88 & 57.5 & 0.46 & 75.3 & 1.74 & 71.4 & 9.65 \\
\hline Ūla & $\mathrm{LT}$ & 52.6 & 1.42 & 641 & 25.5 & 13.9 & 0.61 & 57.6 & 1.56 & 75.3 & 1.39 & 87.4 & 4.74 \\
\hline Aura DS & $\mathrm{LT}$ & 49.1 & 1.22 & 639 & 30.9 & 14.3 & 0.61 & 57.0 & 0.66 & 75.1 & 1.04 & 81.9 & 9.03 \\
\hline Alsa & $\mathrm{LT}$ & 46.5 & 1.03 & 625 & 29.6 & 14.2 & 0.75 & 58.3 & 0.42 & 76.2 & 1.17 & 80.2 & 8.22 \\
\hline Antto & $\mathrm{SE}$ & 46.5 & 1,38 & 655 & 20.5 & 13.5 & 0.93 & 59.4 & 1.56 & 77.5 & 0.68 & 81.6 & 6.27 \\
\hline Scarlett & $\mathrm{DE}$ & 45.1 & 2.05 & 655 & 24.8 & 13.9 & 1.32 & 60.6 & 0.52 & 79.9 & 1.07 & 86.7 & 8.64 \\
\hline Tocada & $\mathrm{DE}$ & 46.8 & 2.88 & 631 & 15.0 & 12.9 & 1.17 & 59.8 & 0.56 & 78.7 & 1.13 & 79.4 & 6.82 \\
\hline 7661-1 & $\mathrm{LT}$ & 47.6 & 3.18 & 687 & 9.8 & 13.4 & 0.99 & 59.3 & 0.97 & 77.5 & 0.67 & 78.7 & 11.18 \\
\hline $7695-4$ & $\mathrm{LT}$ & 47.3 & 2.16 & 678 & 15.0 & 13.5 & 1.22 & 56.3 & 1.10 & 74.1 & 1.13 & 72.7 & 10.23 \\
\hline 7939-1 & $\mathrm{LT}$ & 43.6 & 2.47 & 654 & 18.9 & 13.4 & 1.04 & 58.3 & 0.06 & 77.1 & 0.27 & 72.0 & 6.99 \\
\hline $8080-4$ & $\mathrm{LT}$ & 45.2 & 2.08 & 684 & 12.0 & 13.9 & 1.33 & 59.4 & 1.54 & 77.1 & 1.13 & 76.0 & 8.23 \\
\hline 8096-4 & $\mathrm{LT}$ & 45.6 & 2.67 & 679 & 13.1 & 14.2 & 1.10 & 59.6 & 1.09 & 76.8 & 1.77 & 75.1 & 8.60 \\
\hline 8163-1 & $\mathrm{LT}$ & 45.4 & 3.21 & 680 & 8.1 & 14.1 & 0.24 & 57.0 & 0.44 & 77.7 & 1.13 & 82.6 & 4.33 \\
\hline $7967-2$ & $\mathrm{LT}$ & 43.0 & 2.68 & 670 & 20.8 & 12.9 & 0.90 & 60.8 & 0.95 & 78.9 & 0.73 & 75.0 & 16.65 \\
\hline LSD05 & & 0.63 & & 4.81 & & 0.73 & & 0.88 & & 1.19 & & 9.91 & \\
\hline
\end{tabular}

* LT - Lithuania, DE - Germany, DK - Denmark, SE - Sweden 
$2.5 \mathrm{~mm}$ yield was obtained in 2006. The conditions for barley growing in that year were unfavourable and plants started to wither. At the grain filling stage, green leaves and chlorophyll amount assist in assimilating solar energy and synthesising grain storage material (Triboi and TriboiBlondel, 2002). Thus, in 2006 dry and warm weather significantly affected grain size, which resulted in a low grain $>2.5 \mathrm{~mm}$ yield and high variation among breeding lines. However, these poor conditions allowed for breeders to evaluate the properties of breeding lines. The variation of grain $>2.5 \mathrm{~mm}$ yield was higher than that of grain yield and extract yield and consequently is a more important parameter in the evaluation of ability of varieties and breeding lines to realize their genetic potential in various growing conditions. In Lithuanian agroclimatic conditions (with the hydrothermal coefficient during the grain setting-filling period ranging from 0.6 to 1.6 ) the variation of spring barley varieties and breeding line grain yield, grain $>2.5 \mathrm{~mm}$ yield and extract yield is determined by the weather conditions $(P<$ 0.01 ), which has greater impact than that of genotype. Our demonstrated environmental effect on the grain quality of spring barley is in good agreement with that obtained in Latvia (Bleidere et al., 2008).

Integral evaluation of varieties and breeding lines based on rank evaluation sum by grain yield and stability was introduced in the breeding programme (Kang, 2003). This or analogous programmes are successfully used for the selection of promising breeding material of grasses and cereals (Tarakanovas, 2004; Gomez-Becera et al., 2006). Although the control malting variety 'Barke" was equal by the yield data to 'Scarlett', it exhibited lower yield stability characteristics. In the trials of other researchers, in contrasting weather conditions both varieties ('Scarlett' and 'Barke') showed similar results. The variety 'Scarlett' is characterised by a higher grain yield (Lazauskas et al., 2005). This variety was characterised as having higher grain yield among the spring barley varieties also in Estonia (Tamm, 2003). High integral assessment value was observed for the lines 7967-2 (20+), 7661-1 (15+), 7939-1 (12+), and 8080-4 $(11+)$. The poorest assessment was for the old Lithuanian variety 'Auksiniai 3'. Despite this, the grain of this variety has good malting characteristics and can be included in breeding programmes.

Grain grading is an important parameter both for food and for malt barley. A grain grading $(>2.5 \mathrm{~mm})$ percentage over $90 \%$ required longer duration of the grain filling period (Schelling et al., 2003). Weather conditions had the strongest influence on the length of grain filling period. Lack of moisture over this period does not allow varieties completely to realise their genetic features and causes lower variability in grain grading percentage. According to grain $>2.5 \mathrm{~mm}$ yield of spring barley varieties and breeding lines, the highest integral assessment was obtained for varieties 'Tocada' (17+), 'Sebastian' (16+), 'Scarlett' (12+), 'Barke' (11+), 'Aura DS' (10+) and breeding line 8163-1 (9+).

Integral assessment of extract yield of breeding lines confirms that some lines are distinguished by this parameter.
High integral assessment value was found for varieties 'Tocada' (21+), 'Sebastian' (11+), 'Scarlett' (7+), 'Barke' (8+) and lines: 7967-2 (20+); 7939-1 (14+); 8080-4 (10+), 7661-1 (9+). These lines combine high extract yield with low variance of stability $\left(\delta^{2}\right)(0.004-0.031)$ and are distinguished by high extract content. The breeding line 7967-2 was given as especially high integral assessment value for grain and extract yield $(20+)$, but by grain grading $>2.5$ $\mathrm{mm}$ the integral assessment was low (-9). On the basis of the sum of integral assessments the final value of the breeding lines tested was determined. The highest sum of assessment of grain yield, grain grading and extract yield were obtained by the varieties 'Tocada' (59+), 'Sebastian' (30+), 'Scarlett' (26+) and lines 7939-1 (33+), 7661-1 (30+), and 8080-4 (28+). The variety 'Tocada' and breeding lines 7967-2 and 8080-4 are characterised by high grain yield (4.9-5.2 $\mathrm{t} \mathrm{ha}^{-1}$ ) and significantly out-yielded the standard variety 'Barke'. The spring barley varieties 'Auksiniai 3' and 'Aidas' received a poor assessment. The variety 'Ūla' was distinguished by a high TKW and grain grading, however, the sum of assessments of grain yield, grain grading and extract yield was negative (-8). 'Aidas' and 'Üla' were selected for the feeding purposes, whereas 'Auksiniai 3' is an old and not high-yielding variety, which can explain the above results. The breeding lines that showed high grain stability and were distinguished by high grain quality and other agronomic traits were involved in further breeding programmes. The evaluation by the programme STABLE gave the highest sum of assessments for grain yield, grain grading and extract yield for the varieties 'Tocada', 'Sebastian', 'Scarlett' and breeding lines 7939-1, 7661-1, 8080-4. These varieties and breeding lines are distinguished by low protein and high starch and extract content in grain.

\section{ACKNOWLEDGEMENTS}

This work was supported by the Lithuanian programme of plant gene resources „, The Scientific Researches of Plant Gene Resources".

\section{REFERENCES}

Anonymous (2006). Lietuvos statistikos metraštis. Pasèliai 2006. Vilnius: Statistikos departamentas prie Lietuvos Respublikos Vyriausybės, pp. 414-416 (in Lithuanian)

Bail, M., Meynard, J.M. (2003). Yield and protein concentration of spring malting barley: The effects of cropping systems in the Paris Basin (France). Agronomie, 23, 13-27.

Bleidere, M. (2008). Genetic and environmental effect on the grain quality of spring barley. Agronomijas Vestis, 11, 33-38.

Bukantis, A. (2001). Climatic fluctuations in Lithuania against a background of global warming. Acta Zool. Lituanica, 11(2), 113-120.

Costa, J.M., Bollero, G. (2001). Stability analysis of grain yield in barley (Hordeum vulgare) in US mid-Atlantic region. Ann. Appl. Biol., 139(1), 137-143.

Eagles, H.A., Bedgood, A.G., Panozzo, J.F., Martin, P.J. (1995). Cultivar and environmental effects on malting quality in barley. Aust. J. Agric. Res., 46, 831-844

Gomez-Becera, H.F., Morgunov, A., Abugalieva, A. (2006). Evauation of grain yield stability, reliability and cultivar recommendations in spring 
wheat (Triticum aestivum L.) from Kazakhstan and Siberia. J. Cent. Eur. Agriculture, 7(4), 649-660.

Ivoilov, A.V., Kopylov, V.I., Samoilova, O.N. (2003). The response of barley cultivars to mineral fertilizers in the zone of unsteady moistening. Agrochimija, 9, 30-4 (in Russian).

Kang, M.S., Magari, R. (1995). STABLE: A BASIC program for calculating stability and yield stability statistics. Agron. J., 87, 276-277.

Kang, M.S. (ed.) (2003). Handbook of Formulas and Software for Plant Geneticists and Breeders. New York: Haworth Press Inc. 352 pp.

Lazauskas, S., Semaškienè, R., Paplauskienė, V. (2005).The effect of nitrogen fertilizers and fungicides on the yield and grain size of malting barley varieties under contrasting meteorological conditions. Agriculture, 92, 52-65 (in Lithuanian).

Leach, R., Li, Y., Edney, M., Izydorczyk, M., Egi, A. Sawatzky, K. (2002). Effects of barley protein content on barley endosperm texture, processing condition requirements, and malt and beer quality. MBAA, 39(4), 191-202.

Mašauskienè, A., Paplauskienè, V., Leistrumaité, A. (2001). The effect of cultivar on the variation of spring barley grain quality and yield and correlation among these indicators. Agriculture, 73, 194-209 (in Lithuanian).

Molina-Cano, J.L., Francesch, M., Perez-Vendrell, A.M., Ramo, T., Volttas, J., Brufau, J. (1997). Genetic and environmental variation in malting and feed quality of barley. J. Cereal Sci., 25, 37-47.

Passarella, V., Savin, R., Slafer, G. (2005). Breeding effects on sensitivity of barley weight and quality to events of high temperature during grain filling. Euphytica, 141(1-2), 41-48.

Received 24 September 2008
Paynter, B.H., Young, K.J. (2004). Grain and malting quality in two-row spring barley are influenced by grain filling moisture. Aust. J. Agric. Res., 55, 539-550

Samarah, N.H. (2005). Effects of drought stress on growth and yield of barley. Agron. Sustain. Devel., 25, 145-149.

Schelling, K., Born, K., Weissteiner, C., Kühbauch, W. (2003). Relationships between yield and quality parameters of malting barley (Hordeum vulgare L.) and phenological and meteorological data. J. Agron. Crop Sci., 189, 113-122.

Shukla, G.K. (1972). Some statistical aspects of partitioning genotype - environment components of variability. Heredity, 29, 237-245.

Tamm, I., Tamm, U. (2002). Genetic and environmental variation of malting barley and oat grain quality characteristics. Agriculture, 78, 51-57.

Tamm, U. (2003). The variation of agronomic characteristics of European malting barley varieties. Agron. Res., 1, 99-103.

Tarakanovas, P., Raudonius, S. (2003). Agronominiu tyrimu duomenu statistine analizé taikant kompiuterines programas ANOVA, STAT, SPLIT-PLOT iš paketo SELEKCIJA ir IRRISTAT. Akademija, 57 pp. (in Lithuanian)

Tarakanovas, P. (2004). Dry matter yield stability in cocksfoot varieties. Agric. Sci., 4, 8-14.

Triboi, E., Triboi-Blondel, A.M. (2002). Productivity and grain or seed composition: A new approach to an old problem - invited paper. Eur. J. Agron., 16, 163-186.

Zhang, G.P., Chen, J.X., Dai, F., Wang, J.M., Wu, F.B. (2006). The effect of cultivar and environment on beta-amylase activity is associated with the change of protein content in barley grains. J. Agron. Crop Sci., 192, 43-49.

\section{G̦ENĒTISKO RESURSU NOVĒRTĒŠANA UN IZMANTOŠANA VASARAS ALUS MIEŽU SELEKCIJĀ LIETUVĀ}

Novērtētas alus īpašības 47 vasaras miežu škirnēm un 55 selekcijas līnijām. Apspriesta to izmantošanas perspektīva jaunu, Lietuvas audzēšanas apstākḷiem piemērotu alus miežu škirṇu selekcijā. 